3. Капранова В. А. Проектное обучение в вузе: исторические и технологические аспекты // Известия БГПУ. 2014. №3 (264). С. 78

4. Гузеев В. В. Образовательная технология: от приёма до философии. М.: Высшая школа, $1996.368 \mathrm{c}$.

5. Полат Е. С. Метод проектов. URL: / http://www.ioso.ru/distant/project/methproject/metod pro.htm

6. Ахметов М. А. Проектный метод обучения // Химия в школе. 2012. №. 3

7. Матяш Н. В. Психология проектной деятельности школьников в условиях технологического образования. Мозырь: [Б.и ]. М. 2000. C. 127.

8. Парфенова Т. А. Формирование проектной компетентности будущих педагогов в условиях вуза [Электронный pecypc]. URL: http://teoria practica.ru/rus/files/arhiv_zhurnala/

013/10/pedagogika/parfenova.pdf

9. Miєp T. I. Дидактичні засади організації навчально-дослідницької діяльності молодших школярів: дис... док. пед. наук. К. 2017. 594 с.

\section{REFERENCES}

1. Ministerstvo osvity' i nauky' Ukrayiny`. (2016). Nova ukrayins `ka shkola. Konceptual’ni zasady' reformuvannya seredn 'oyi osvity'. [New Ukrainian school. Conceptual foundations of reform of secondary education]. Kyiv.

2. Ency 'klopediya osvity (2008). [Encyclopedia of education]. Kyiv.

3. Kapranova, V. A. (2014). Proektnoe obuchenie $v$ vuze: istoricheskie $i$ tekhnologicheskie aspekty'. [Project-based learning in the University: historical and technological aspects]. Minsk.

4. Guzeev, V. V. (1996). Obrazovatelnaya tehnologiya: ot priëma do filosofii. [Educational technology: from receipt to philosophy]. Moskva.

5. Polat, E. S. Metod proektov. [Project method].
6. Ahmetov, M. A. (2012). Proektnyiy metod obucheniya. [The project method of teaching]. Kyiv.

7. Matyash, N. V. (2000). Psihologiya proektnoy deyatelnosti shkolnikov $v$ usloviyah tehnologicheskogo obrazovaniya. [ The psychology of design activity of pupils in conditions of technological education]. Moskva.

8. Parfenova, T. A. (2013). Formirovanie proektnoy kompetentnosti buduschih pedagogov $v$ usloviyah vuza. [Formation of design competence of future teachers in the conditions of the University].

9. Miier, T. I. (2017). Dydaktychni zasady orhanizatsii navchalno-doslidnytskoi diialnosti molodshykh shkoliariv. [Didactic basis of the educational-research activity of younger schoolchildren]. Kyiv.

10. Savenkov, A. I. (2006). Psihologicheskie osnovyi issledovatelskogo pohoda $k$ obucheniyиюю. [Psychological basis of the research of campaign for learning]. Moskva.

\section{ВІДОМОСТІ ПРО АВТОРА}

ПРІМА Дмитро Анатолійович - кандидат педагогічних наук, старший викладач кафедри соціальної роботи і педагогіки вищої школи Східноєвропейського національного університету імені Лесі Українки.

Наукові інтереси: формування професійної позиції майбутнього вчителя початкової школи.

\section{INFORMATION ABOUT THE AUTHOR}

PRIMA Dmitro Anataliyovych - Candidate of Pedagogical Sciences, Senior Lecturer in the Department of Social Work and Pedagogy of the Higher School, Lesya Ukrainka Eastern European National University.

Circle of scientific interests: formation of the professional position of future teacher of primary school.

Стаття надійшла до редакиї 15.07.2020 p.

РОЖАК Наталія Володимирівна -

кандидат педагогічних наук, доцент Львівського національного університету імені Івана Франка ORCID:https://orcid.org/0000-0002-6872-2531

e-mail: sulymn@ukr.net

МИКИТЕНКО Марія Михайлівна -

аспірант кафедри початкової та дошкільної освіти Львівського національного університету імені Івана Франка

ORCID:https://orcid.org/0000-0002-2311-5391 e-mail: mykytenkomariia@gmail.com

\title{
THE ROLE OF MULTIMEDIA IN THE PROCESS OF INTENSIFICATION OF FOREIGN LANGUAGE CLASSES
}

Formulation and justification of the relevance of the problem. Nowadays, information technology has become an integral part of our lives. It is now virtually impossible to find an area of human activity where part of the tasks would not be solved by a computer and the Internet. The active use of information technology is also observed in higher education. 
The use of information technologies in the educational process provides a large informative capacity of the language material, increasing the cognitive activity of students, increasing motivation through the emotional presentation of educational information, a high degree of clarity of the educational material, promotes the differentiation of students' activities, taking into account their individual features. Recent advances in high technology provide teachers with great opportunities to intensify the learning process and translate it into a brand new foundation. There is an opportunity to transfer information by various software and hardware, which allow it to be processed in sound and visual form. The greatest effect here is achieved by the use of multimedia tools.

Analysis of recent research and publications. M. Boremchuk, L. Koltok, E. Subotina, S. Fomin pay special attention to the study of the use of Internet resources in teaching foreign languages to future specialists. The general theories of the use of multimedia in education are covered in the works of V. Ageev, V. Baharev, V. Bykov, A. Vasyura, B. Gershunsky, I. Gordeev, M. Gurzhia, R. Gurevich, A. Ershov, PM Zhdanovich, G. Kleiman, K. Colin, L. Konoshevsky, O. Konoshevsky, N. Robert, R. Seleznev, O. Shlikova. Study of multimedia that are implemented in the process of foreign language classes devoted to the works of local and foreign scientists, such as: J. Beztin, R. Bolito, O. Buzdugan, P. Viddosvon, S. Kozhushko, V. Korzh, Moskvina, V. Nasonova, N. Nikitina, A. Waters, T. Hutchinson, P. Shpirko. Pedagogical and methodological aspects of the use of multimedia in the process of intensification of foreign language classes are also sufficiently thoroughly considered in the studies of T. Vakolyuk, M. Vasilovskaya, Y. Galon, Y. Gromova, V. Lyudis, I. Mural, E. Nosenko, O. Sukhovirsky, G. Cherednichenko, O. Shiman, V. Shakotko.

Coverage of previously unresolved parts of the general problem addressed by the article. Although the study of the organization of the initial process with the use of modern information and communication technologies is a relevant area in pedagogy, it is worth paying more attention to the introduction of multimedia tools while conducting foreign language classes.

The purpose of the paper is to determine the role of multimedia in the process of intensification of foreign language lessons.

The main material of the study.
Multimedia and the Internet provide ample opportunities to increase efficiency, intensify the learning process through interactivity, individualize the learning process, and enhance student motivation. The intensification of learning should be understood as improving the productivity of the teaching work of the teacher and the student for each unit of time. In order to keep the workload at an acceptable level, not to lead to overload, not to make negative reflection on health and at the same time, to organize work of the teacher and the student highly effective, it is necessary to choose the optimal methods of teaching. Therefore, the intensification and optimization of classes should be carried out using the most important multimedia means of organizing teaching. Implementing them in educational practice helps to overcome formalism in teaching and the transition from dogmatic to creative construction of the educational process [10, p. 87].

Nowadays, such concepts as «multimedia», «multimedia technologies», «multimedia tools» are being used in the educational process. Thus, the term «multimedia» (from lat multum - many and media medium - cell, means) in the encyclopedic dictionary is treated as an electronic medium of information, which includes several of its types (text, images, animation, etc.). In other words, it is a collection of computer technologies that simultaneously use several information environments: graphics, text, video, photography, animation, sound effects, high-quality soundtrack; multimedia shell program; a product made on the basis of multimedia technology; computer equipment.

Therefore, «multimedia» should be understood as the interaction of visual and audio effects under the control of interactive software. Usually, this means a combination of text, sound and graphics, and more recently animation and video.

The scientist V. Korzh defines «multimedia technologies» as a set of audio-video and other means of displaying information, which are integrated in the interactive programming environment. Yu. Moskvina understands multimedia media as information technologies that use different software and hardware for the most productive influence on students.

It should be noted that multimedia means are different from traditional ones, first of all in that [2]:

1) information (data) is stored and processed digitally using a computer;

2) they can contain different types of 
information (not only text, but also audio, graphics, animation, video);

3) their essential feature is interactivity active interaction of a resource, program, service and person and their mutual influence. The user can take one or another online product and immediately add to it their own materials, thereby acting as its co-author;

4) presence of hypertext.

It is important that multimedia is an effective learning tool in the intensification of classes that contain elements inherent in any didactic system. Now, multimedia programs are an additional means of organizing the learning process within the traditional education system. They provide an opportunity to increase the motivation and intensification of learning through the use of modern methods of processing audiovisual information. In other words, a modern computer allows didactic developers to use a range of verbal and nonverbal tools that they have never had before. These tools allow you to create aesthetic, interesting, informative, problematic materials, namely to solve the problem of intelligence given at different stages of learning, and thus increase motivation [3, p. 119].

Analyzing the methods and approaches of domestic and foreign authors on the process of intensification of foreign language lessons, the following characteristic features of intensive learning can be distinguished (Fig. 1):

According to research by D. Johnson and M. V. Clarina pedagogical methods and techniques used in the process of intensification of foreign language teaching by means of multimedia in higher education institutions (Universities) can be classified as [8; 9]:

- teaching methods through student interaction with educational resources with minimal teacher involvement. The development of these methods is characterized by a multimedia approach, when using various means to create educational resources: printed, audio, video and educational materials coming from computer networks;

- methods of individualized teaching and learning that are characterized by the relationship of one student with one teacher or one student with another student (one-to-one teaching);

- methods based on providing students with instructional material when students do not play an active role in communication (one-to-many teaching). These methods, inherent in the traditional education system, are getting new development based on modern information technologies;

- methods characterized by active interaction between all participants in the educational process (many-to-many learning). The development of these methods is associated with the conduct of collective discussions, roleplaying games and polylogist presentations.

As a result, with the ability to store and share a large amount of text, audio and visual material, multimedia technologies have become a powerful and convenient means of supporting and enriching the educational process when teaching foreign languages [2].

Open Internet access increases the ability of students to study foreign languages. Using the network, it is easy to find new authentic texts, electronic textbooks, directories, foreign newspapers and magazines that meet the interests of students and their specialties. Such materials are interesting and intimate, students readily work with them, read and discuss them. Thus, the skills of reading, reading comprehension, translation and speaking are improved [6, p. 231].

Recently multimedia technologies became the main means of teaching students foreign languages. Multimedia technologies aimed at developing languistic and communicative skills. High-volume multimedia products on a variety of electronic media (USB Flash, CD, DVD) include encyclopedias, dictionaries, educational games [13].

The main types of multimedia in the scientific and pedagogical literature include: computer games; multimedia business applications; educational programs; special programs designed for the self-production of various multimedia products (both amateur and professional) [7].

In addition, multimedia that can be used in the learning process include interactive whiteboard, multimedia projector, laptop or netbook, multimedia player, smartphones and communicators, etc. [4, p. 11].

From our point of view, during the correct and systematic use of multimedia tools in the classroom, the volume of the learned educational material is increased several times and a high degree of mastery of foreign languages is achieved.

The forms and location of the use of multimedia technologies in foreign language classes depend, of course, on the content of the lesson and on the goal set by the teacher. However, the practice makes it possible to identify some of the most common, most effective methods of using such tools: 


\begin{tabular}{|c|c|c|c|c|}
\hline Mastering a foreign & $\begin{array}{c}\text { Foreign language } \\
\text { language in a short } \\
\text { time by mobilizing the } \\
\text { resources of the } \\
\text { individual and his/her learned, it } \\
\text { is used through } \\
\text { communication }\end{array}$ & $\begin{array}{c}\text { Classes start with } \\
\text { communication, } \\
\text { not learning the } \\
\text { grammar rules }\end{array}$ & $\begin{array}{c}\text { Foreign language } \\
\text { training takes the } \\
\text { form of a role- } \\
\text { playing game }\end{array}$ & $\begin{array}{c}\text { A multimedia approach } \\
\text { based on the use of several } \\
\text { complementary information } \\
\text { technologies is more } \\
\text { effective }\end{array}$ \\
\hline
\end{tabular}

1. When learning new material. Multimedia technologies allow to illustrate new (both grammatical and vocabulary) material with a variety of visual and cognitive tools. Application is especially advantageous when it is necessary to show the dynamics of the development of any process.

2. For testing. Computer testing is selftesting and self-realization thing, it is a good stimulus for learning, it is a way of activity and expression of oneself. For the teacher, it is a mean of quality control of knowledge, a programmable way of accumulating grades. First of all, multimedia tools neutralize the punishment function of the teacher, since the assessment takes place automatically and without the direct involvement of the teacher. It should be noted that the computer removes such a negative psychological factor as «fear». During traditional classroom activities, various factors (defects in pronunciation, fear of making mistakes, inability to formulate their thoughts aloud, etc.) do not allow many students to show their real knowledge. Staying «alone» with the display, the student, as a rule, does not feel tight and tries to show the maximum of their knowledge.

3. To deepen knowledge with a supplementary material to the lessons. Yes, the use of a multimedia projector allows to demonstrate multimedia presentations, training videos, tables and charts, as well as multimedia educational games. The combination of graphics, animation, photos, video and audio in interactive mode of learning, activates the work of all sensory channels of students and creates an integrated information environment in which new opportunities for learning foreign languages are opened at the university. Small groups require the use of a laptop or multimedia player to present a new topic, develop listening skills, work with an electronic textbook or tutorial, watch training videos, write business emails, or browse advanced foreign periodicals with Internet access, use programs in foreign language, check students' independent work, for example, in the form of multimedia presentation and more.

\section{When checking independent work.}

Optimization of independent work can be achieved with the help of multimedia. The important point here is that when working with a multimedia program, the learning material is perceived through not only visual (text, color, still images, videos, animations) but also hearing (speaker or actor voice, music or noise), which allows to create a given emotional background, which increases the efficiency of assimilation of the given material [1, p. 52].

The interesting thing is that there is an increase in the objectivity of students' knowledge assessment, the teacher begins to perform the role of a consultant, thus ceasing to be a source of negative emotions. There is an inability to control or test students' knowledge using innovative technologies to identify or encourage «favorite students», on the other hand, making it difficult for them to prompt or write off. In general, it can be noted the positive aspects of the use of computer technology, such as increasing the speed and accuracy of the results of the assessment and evaluation of objectivity and impartiality.

5. When solving problems of educational character. It helps execute and control intermediate and final work results. The student can use the computer both to study individual topics and to self-control the acquired knowledge. In this case, the computer can repeat the same task as long as possible, and in the end, this leads to such a useful phenomenon as the automation of a skill. The computer has many technical features: graphics, sound, animation, which makes it attractive to students. But the main thing that differentiates a computer from other learning avenues is the possibility of informal dialogue when the computer asks a question, and the student must answer in the strictly defined frameworks of interactive dialogue: when the personality becomes the main in the dialogue, when it imposes a computer or teaches him or her to make certain actions.

The most effective way of teaching of foreign languages is the intensification process, which includes discussion, intense mental 
activity and collective activity. A promising area of work in the system of intensification of foreign language lessons is an integrated approach to solving the main tasks, which combine: a complex of multimedia technologies with high didactic potential, telecommunication technology, computer learning of foreign languages and methods of intensive language learning.

The use of multimedia in the process of intensification of foreign language lessons has the following advantages: it teaches «live» spoken language; gives the opportunity to speak, starting with the first lesson; gets acquainted with the culture and traditions of the language being taught; takes into account the individual needs of each; helps to overcome the language barrier; provides for maximizing the volume of educational material; takes place in a friendly informal atmosphere [5].

Therefore, the introduction of multimedia, as an auxiliary tool in the process of teaching a foreign language in high school, gives the opportunity to develop and implement pedagogical, methodological, didactic and psychological principles. The use of innovative technologies in foreign language classes can improve the quality of learning, develop cognitive activity of the student, his independence in the study, search, selection and processing of information.

It is important that the use of multimedia technologies in the educational process allows to increase the efficiency of learning due to stimulation of the greatest number of feelings of the student; use of various forms of work with the computer, which contributes to the formation of skills in them, which in other educational computer environments it is almost impossible to form.

Conclusions and prospects for further researches of direction. Thus, the process of learning a foreign language is a complex and constantly evolving system. Teachers need to take advantage of the opportunities that exist in today's world. Today, they are multimedia. They are effective educational technologies due to their inherent qualities of interactivity, flexibility and integration of different types of educational information, as well as the ability to take into account the individual characteristics of students and to enhance their motivation. As a result, these tools are included in the educational process as supportive of traditional methods of the education system. Multimedia resources act as the means of intensifying the learning process, individualizing learning and partially automating the work of teachers associated with the measurement and assessment of students' knowledge.

The prospect of further research is the problem of the introduction of multimedia in English classes.

\section{BIBLIOGRAPHY}

1. Baharev, V. Possibilities of multimedia tools in the organization of students' independent work (on the example of studying English). Saransk. 2017.

2. Beztsinna Zh. Application of multimedia tools for optimization of students' independent work in the process of learning a foreign language in a nonlanguage university // Teaching languages in higher education institutions at the present stage. Interdisciplinary connections. Scientific research. Experience. Search, 16. 2010, P. 27-33.

3. Beztsinna, Zh. Advantages of using multimedia tools for organizing independent work of students in the process of learning a foreign language in a non-linguistic higher education institution // Collection of scientific works, 10. 2012, P.117-120.

4. Buzdugan, O. (2015). Use of multimedia learning tools in the context of updating the foreign language teaching process // Science and education, 2. 2015, P.10-15.

5. Vakolyuk, T. Multimedia approach to intensive foreign language teaching at a higher military institution // Scientific journal of the National Academy of the State Border Guard Service of Ukraine, 1. 2010.

6. Vasilovskaya, M. 2008. The use of multimedia as one of the means of intensifying independent work in learning a foreign language // News of the Southern Federal University. 2008, P. 230-234.

7. Gordeeva, I. Multimedia technology // SGGA. Novosibirsk. 2010.

8. Dzhonson, D. Learning Methods. Training in cooperation // SPb. : Economic school. 2001.

9. Klarin, M. V. Pedagogical technology in the educational process. Analysis of foreign experience. Moscow: Knowledge. 1989.

10. Koltok, L. Intensification of the educational process in the light of modern pedagogical discussions // Young people and morning, 8 (79). 2011, P. 87-90.

\section{REFERENCES}

1. Baharev, V. V. (2002). Vozmozhnosti multimediynyih sredstv $v$ organizatsii samostoyatelnoy rabotyi studentov (na primere izucheniya angliyskogo yazyika). [Possibilities of multimedia tools in the organization of students' independent work]. Saransk.

2. Beztsinna, Zh. P. (2010). Zastosuvannya mul'tymediynyh zasobiv dlya optimizatsiyi samostiynoyi roboty studentiv u protsesi navchannya inozemnoyi movy $v$ nemovnomu VNZ. [Application of multimedia tools for optimization of students' independent work in the process of learning a foreign language in a non-language university]. 
3. Beztsinna, Zh. P. (2012). Perevagy vykorystannya mul'tymediynyh zasobiv dlya organizatsiyi samostiynoyi roboty studentiv u protsesi navchannya inozemnoyi movy $v$ nemovnomu vyshchomu navchal'nomu zakladi. [Advantages of using multimedia tools for organizing independent work of students in the process of learning a foreign language in a non-linguistic higher education institution].

4. Buzdugan, O. A. (2015). Vykorystannya mul'tymediynyh zasobiv navchannya $v$ konteksti osuchasnennya protsesu vykladannya inozemnoyi movy. [Use of multimedia learning tools in the context of updating the foreign language teaching process].

5. Vakolyuk, T. V. (2010). Mul'tymediyniy pidhid do intensyvnogo navchannya inozemnoyi movy u vyshchomu viyskovomu navchal'nomu zakladi. [Multimedia approach to intensive foreign language teaching at a higher military institution].

6. Vasilovskaya, M. N. (2008). Ispolzovanie multimedia kak odnogo iz sredstv intensifikatsii samostoyatelnoy rabotyi pri izuchenii inostrannogo yazyika. [The use of multimedia as one of the means of intensifying independent work in learning a foreign language].

7. Gordeeva, I. V. (2010). Multimedia tehnologiya. [Multimedia technology]. Novosibirsk.

8. Dzhonson, D. (2001). Metodyi obucheniya. Obuchenie $v$ sotrudnichestve. [Learning Methods. Training in cooperation].

9. Klarin, M. V. (1989). Pedagogicheskaya tehnologiya $v$ uchebnom protsesse. Analiz zarubezhnogo opyita. [Pedagogical technology in the educational process. Analysis of foreign experience]. Moskva.
10. Koltok, L. (2011). Intensyfikatsiya navchalno-vyhovnogo protsesu v svitli suchasnyh pedagogichnyh dyskusiy. [Intensification of the educational process in the light of modern pedagogical discussions].

\section{ВІДОМОСТІ ПРО АВТОРА \\ РОЖАК Наталія Володимирівна - кандидат педагогічних наук, доцент Львівського національного університету імені Івана Франка. \\ Наукові інтереси: методика викладання іноземних мов.}

МИКИТЕНКО Марія Михайлівна аспірант кафедри початкової та дошкільної освіти Львівського національного університету імені Івана Франка.

Наукові інтереси: методика викладання іноземних мов.

\section{INFORMATION ABOUT THE AUTHOR}

ROZHAK Nataliya Volodymyrivna Candidate of Pedagogical Sciences, Associate Professor of Ivan Franko National University.

Circle of scientific interests: methodology of teaching foreign languages.

MYKYTENKO Maria Mykhailivna Postgraduate Student of the Department of Primary and Preschool Education of Ivan Franko National University.

Circle of scientific interests: methodology of teaching foreign languages.

Стаття надійшла до редакиії 18.07.2020 p.
ФЕСЕНКО Оксана Сергіївна кандидат педагогічних наук, доцент кафедри початкової та дошкільної освіти КЗВО «Дніпропетровська академія неперервної освіти» ДОР ORCID:https://orcid.org/0000-0003-3666-3861 e-mail:777oxana7@i.ua

\section{ІННОВІЦІЙНИЙ ПІДХІД ДО ЗАСТОСУВАННЯ ІГРОВИХ МЕТОДІВ У НОВІЙ УКРАЇНСЬКІЙ ШКОЛІ}

\begin{abstract}
Постановка та обгрунтування актуальності проблеми. У контексті реформи «Нова українська школа» модернізація науково-освітнього простору визначає необхідність професійного вдосконалення й підвищення рівня професійної компетентності вчителів початкової школи. Уміння будувати власну професіограму в освітньому просторі через самовдосконалення, мобільність, відкритість
\end{abstract}

до інновацій є важливими і необхідними в умовах сьогодення. Отже, питання впровадження в освітній процес інноваційних підходів, зокрема до застосування ігрових методів в умовах реформування Нової української школи, $є$ своєчасним i актуальним.

Аналіз останніх досліджень i публікацій. Сучасна освітня система характеризується як глобальна система, 